
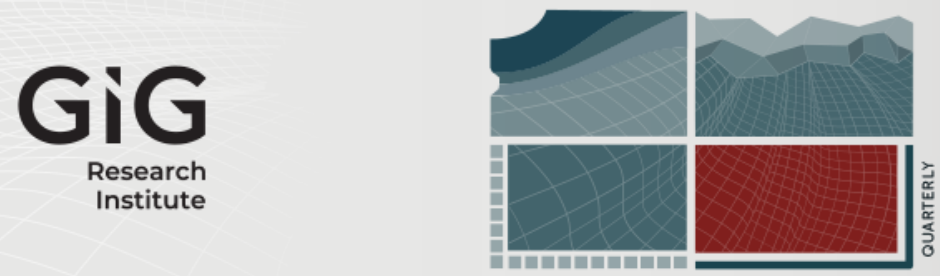

JOURNAL

OF

SUSTAINABLE

MINING

Volume 20 Issue 1

Article 2

2021

\title{
The influence of pressure drop on gas emissions from a mining shaft - an overview
}

Author(s) ORCID Identifier:

Paweł Wrona (iD 0000-0001-5978-4039

Zenon Różański (iD) 0000-0002-0483-7276

Grzegorz Pach (iD) 0000-0003-2680-3568

Adam Niewiadomski (iD) 0000-0002-4446-5059

Tomasz Suponik (D) 0000-0002-4251-4275

Follow this and additional works at: https://jsm.gig.eu/journal-of-sustainable-mining

Part of the Mining Engineering Commons, and the Sustainability Commons

\section{Recommended Citation}

Wrona, Paweł; Różański, Zenon; Pach, Grzegorz; Niewiadomski, Adam; and Suponik, Tomasz (2021) "The influence of pressure drop on gas emissions from a mining shaft - an overview," Journal of Sustainable Mining: Vol. 20 : Iss. 1 , Article 2.

Available at: https://doi.org/10.46873/2300-3960.1032

This Research Article is brought to you for free and open access by Journal of Sustainable Mining. It has been accepted for inclusion in Journal of Sustainable Mining by an authorized editor of Journal of Sustainable Mining. 


\title{
The influence of pressure drop on gas emissions from a mining shaft - an overview
}

\begin{abstract}
Climate change can make an impact on the mining sector and post-mining sites. Among others, extreme weather events are connected with sudden and deep pressure drops which lead to gas emissions from an underground space to the surface through closed shafts. The tests undertaken in the frameworks of TEXMIN project lead to get measuring data of this phenomenon and will allow validating numerical models for further forecasts and mitigation means. Three examples of the results were presented. They showed that the intensity of pressure drop influences strongly on gas emissions from a closed shaft. Although the pressure drop process should be investigated in detail considering hourly or even more frequent variations of pressure. Considering the variation of emitted gases in the vicinity of the closed shaft they remained increased even $20-30 \mathrm{~m}$ from the point of emissions.
\end{abstract}

\section{Keywords}

mine closure, gas hazard, carbon dioxide emissions

\section{Creative Commons License}

\section{(c) (i)}

This work is licensed under a Creative Commons Attribution 4.0 License.

\section{Cover Page Footnote}

This project has received funding from the Research Fund for Coal and Steel under grant agreement No. 847250 TEXMIN “The Impact of Extreme Weather Events on Mining Operations". Praca naukowa opublikowana w ramach projektu międzynarodowego współfinansowanego ze środków Ministra Nauki i Szkolnictwa Wyższego pn. „PMW” w latach 2019-2022 umowa nr 5009/FBWiS/2019/2

\section{Authors}

Paweł Wrona, Zenon Różański, Grzegorz Pach, Adam Niewiadomski, and Tomasz Suponik 


\title{
The influence of pressure drop on gas emissions from a mining shaft - An overview
}

\author{
Paweł Wrona*, Zenon Różański, Grzegorz Pach, Adam Niewiadomski, Tomasz Suponik
}

Silesian University of Technology, Faculty of Mining, Safety Engineering and Industrial Automation, Poland

\begin{abstract}
Climate change can make an impact on the mining sector and post-mining sites. Among others, extreme weather events are connected with sudden and deep pressure drops which lead to gas emissions from an underground space to the surface through closed shafts. The tests undertaken in the frameworks of TEXMIN project lead to get measuring data of this phenomenon and will allow validating numerical models for further forecasts and mitigation means. Three examples of the results were presented. They showed that the intensity of pressure drop influences strongly on gas emissions from a closed shaft. Although the pressure drop process should be investigated in detail considering hourly or even more frequent variations of pressure. Considering the variation of emitted gases in the vicinity of the closed shaft they remained increased even $20-30 \mathrm{~m}$ from the point of emissions.
\end{abstract}

Keywords: mine closure, gas hazard, carbon dioxide emissions

\section{Introduction}

$\mathrm{M}$ ining is a sector particularly exposed to climate change. Changing climatic conditions will influence both, operating and closed mines. Among other factors, possible impact is related to variations in atmospheric pressure [1]. Assessing and minimising the environmental impact of extreme weather events on mining operations is the aim of TEXMIN project (The impact of extreme weather events on mining operations) founded by Research Fund for Coal and Steal and partly founded by Polish Ministry of Science.

One of the specific goals is to identify, quantify and evaluate those impacts brought about by sudden changes in atmospheric pressure and model them for improvement of the understanding of how changing parameters influence the results. The influence of the buoyancy effect is additional aspect being tested when gas flows from an underground location through a closed shaft to the surface.
Significant and more frequent storms will be associated with deep low-pressure systems. These more frequent changes in atmospheric pressure could lead to more gas emissions (particular $\mathrm{CH}_{4}$ and $\mathrm{CO}_{2}$ ) from underground mines [2-4]. Gas emissions depend on the mining method, the depth of the seams, the coal quality and the entrapped gas content within the coal seam [5]. A gas continues to escape from the old workings of abandoned coal mines where it could reach the surface through cracks and crevices caused by mining activity, from shafts and adits which were not completely sealed, or from degassing boreholes [6]. In general, an increased amount of gas will flow to the atmosphere during barometric pressure drops where the pressure in the reservoir will be greater than the barometric pressure [7], although this phenomenon is still under investigations.

The aim of conducted research is to get deeper knowledge on the process by in situ measurements.

Then, the results will be the base for validation of further numerical emissions models (to simulate predicted extreme weather events). The results will be also used for risk assessment and for

Received 10 November 2020; revised 19 January 2021; accepted 24 January 2021.

Available online 6 March 2021

* Corresponding author.

E-mail address: pawel.wrona@polsl.pl (P. Wrona). 
determination of mitigation methods at post-mining areas [8-11].

It should be emphasized here that the article is referred to one of the possible cases of gas emissions from closed mines - through the decommissioned shaft. It is when there is hydraulic flow of gases through a shaft which is not filled with backfilling material.

This type of flow has already been studied by [i.e. [12]], and later by, for example, Sułkowski and Wrona [13] provided mathematical models of hydraulic flow and applied them to own computer programs enabling their solution. The first model was based on Torricelli equation. It was assumed that the pressure difference at the outlet of the opening from the reservoir is caused by a decreasing barometric tendency. In this model, a constant density of the mixture was assumed, gas expansion, gas viscosity and process isothermal nature were omitted. It was a simplified model. The second model was a model called "complex", which was based on a system of non-linear differential equations describing the transient air flow in the mine ventilation network. This model took into account the inertia of the flow and the compressibility of gases. Since then, the computing capabilities of computers and software have developed. CFD programs such as Ansys Fluent or Pyrosim have been introduced and developed. The results presented in the article will be used to validate the models in these programs.

However, there are other gas flow cases along with the models that describe them:

- Diffusion flow of gases - i.e. the flow taking place due to the concentration gradient of gases between various elements of the carbon matrix or between the centre of a given element and the walls of adjacent fissures or pores, which leads to automatic balancing of gas concentrations in underground workings, goafs and voids [14-16].

- Gas filtration flow through porous material caused by the balancing of gas pressure in all the gaps forming the system of connected vessels. The gas flows under pressure towards the surface through all available gaps. They can be fault gaps, cracks, gaps in porous material filling closed workings and holes $[17,18]$. For example, Dziurzyński [19] developed a model of gas migration from the shaft of a closed mine, but it was assumed that the shaft was completely filled with proppant material and was tightly closed on the surface.

The low permeability of coal seams is the main reason that developing coalbed methane (CBM) as an energy resource is difficult, so increasing coal seam permeability is the key to CBM model development in China [20].

Additionally, other models were created, for instance:

- Geological model - presented by [21]. It was found that a key role in shaping the migration process of mine gases towards the surface is played by the lithological formation and the thickness of the carboniferous overburden, especially in the tertiary and quaternary layers. In the case of thick and impermeable tertiary layers (Miocene), the migration phenomenon is clearly slowed down (symptoms of gas appear on the surface after a much longer period of time - around 30 years) or even impossible.

- Risk model - [22] - This article presents the principles of this methodology. An application example based on a true case study is then described. This is completed by a presentation of the preventive and monitoring resources recommended and usually applied in order to manage the risk linked to gaseous emissions.

This article presents the first step of the research the measurements, by three different examples.

\section{Materials and methods}

\subsection{The site - shaft II}

The shaft is located in an open space area within the revitalized industrial park (Fig. 1).

The shaft II (which is selected for examinations) is located strictly between two buildings. This location creates a kind of a wind tunnel making south winds as dominant. The shaft is empty (not backfilled) because of water pumping purposes.

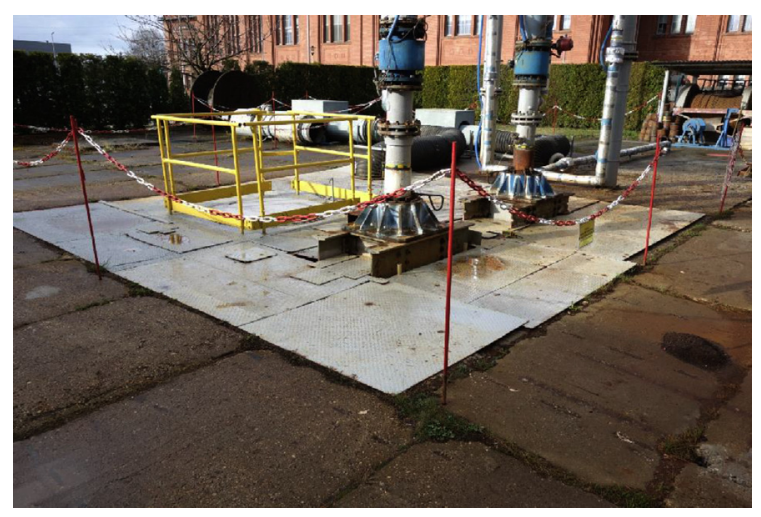

Fig. 1. Location of the shaft II. 


\subsection{Instruments}

Following instruments were applied during the tests:

- MultiRae IR Plus, gas analyser,

- Flir E6 - infrared camera (Fig. 2).

- Nova MRU Plus, gas analyser (Fig. 3),

$-\mu \mathrm{AS}-4$, digital vane anemometer,

$-\mu \mathrm{AS}$, digital vane anemometer,

- Kestrel, portable meteorological station,

\subsection{The method}

The measurements were based on good practice methods recommended in the document prepared by the Intergovernmental Panel of Climate Change (IPCC) which is titled "PCC Guidelines for National Greenhouse Gas Inventories, Volume 2 Energy, Chapter-Fugitive emissions"' (NGER Act 2009) and on an adequate Polish standard (PN-Z-04008-02: 1984).

The research procedure included the following steps:

- Due to determination of the range and the rate of emissions, detection of possible gas velocity and gas concentrations were carried out. It allowed to select adequate measuring instruments and to determine the measuring grid as well as the points of emissions.

- Points of emissions were selected (including the application of IR vision instruments and vane anemometers), then profiles of emissions were determined by the application of gas analysers.

- It was stated that the gas concentration is constant in the profiles. As a result - continuous

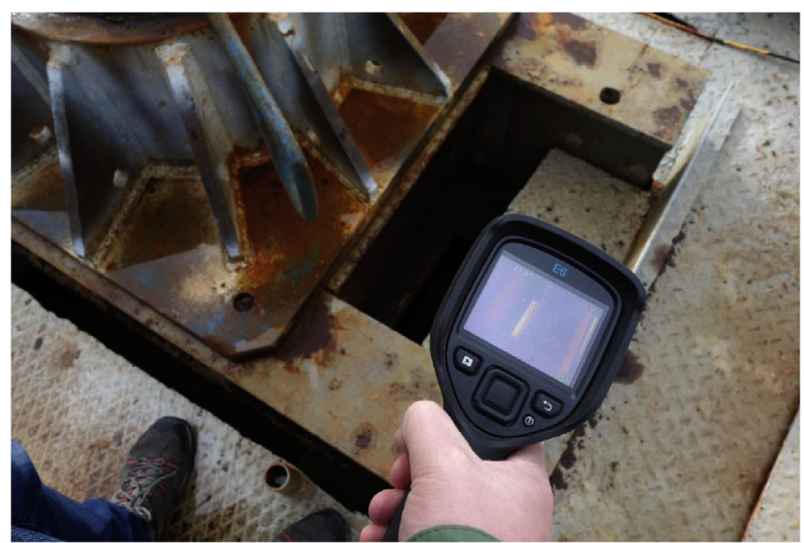

Fig. 2. Application of IR camera for detection of the emissions.

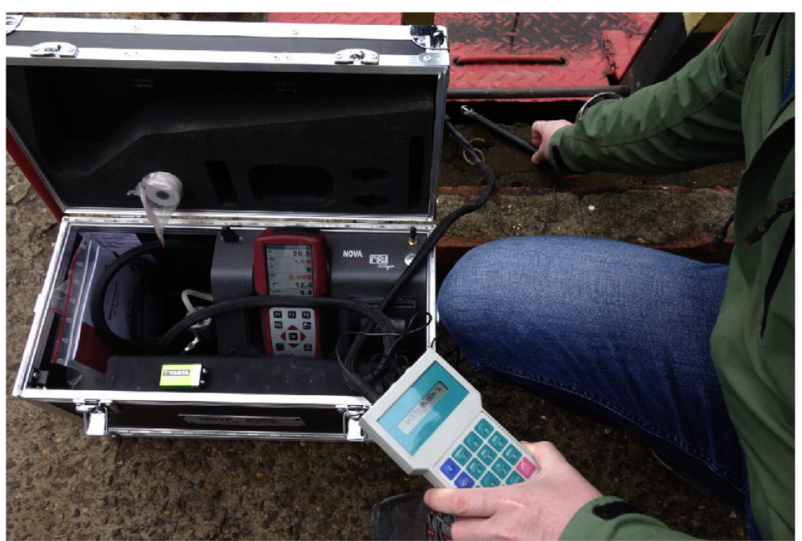

Fig. 3. Gas analyzer and vane anemometer measurements of gas emissions.

traverse method was selected to establish average velocity.

At the same time the measuring mesh was determined around the shaft (Fig. 5). The purpose was to check the variation of gas concentrations in vicinity of the shaft at the ground level and at $1 \mathrm{~m}$ above the ground when pressure drops. The mesh compromises 15 points located in accordance with their availability and safety features. Point ' $E$ ' is an emission point (Figs. 4 and 5).

\section{Results and discussion}

There were eleven series (one preliminary and ten specific series) covering spring 2020 and summer 2020 seasons.

- Example 1 - the results taken on May 23rd 2020 (typical pressure drop) is presented in Figs. 6-8.

- Example 2 - upcoming extreme weather storm, according to the project assumptions, August 22nd 2020 Figs. 9-11.

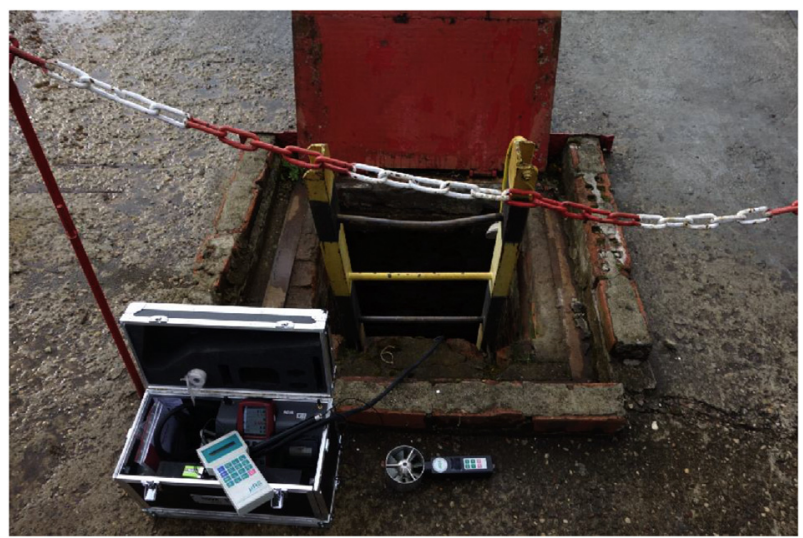

Fig. 4. Determination of the main point of emissions for the shaft II. 


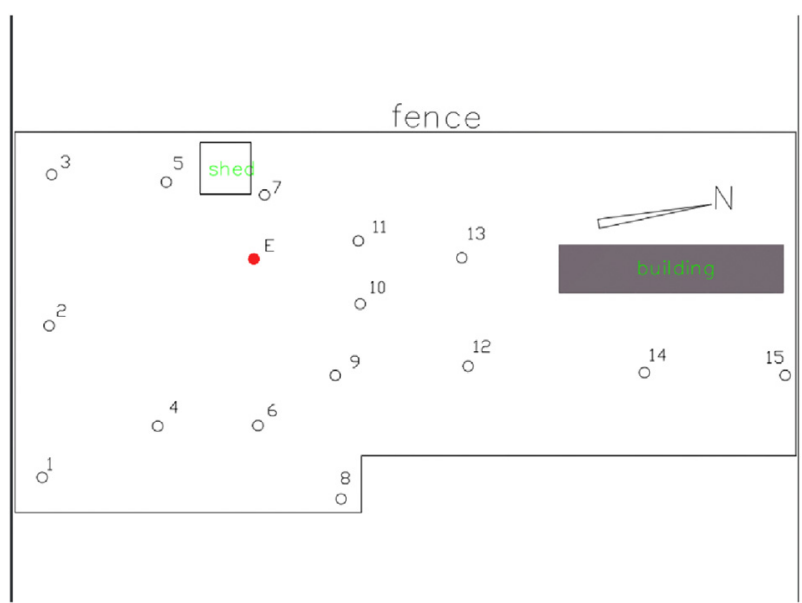

Fig. 5. Measuring points in vicinity of II shaft.

- Example $3-\mathrm{CO}_{2}$ and $\mathrm{O}_{2}$ distribution in vicinity of shaft II, 3rd June 2020, Figs. 12-15.

\subsection{Example 1 - May 23rd 2020}

On May 23, 2020, the tests of gas emissions from shaft II began at 9:00 AM and finished at 6:00 PM. At that time, the atmospheric pressure decreased from $991.7 \mathrm{hPa}$ to $988.6 \mathrm{hPa}$. Therefore, pressure drop was $3.1 \mathrm{hPa}$ within $9 \mathrm{~h}$. There are, however, two stages in the downward trend. The first from 9:00 AM to 1:00 PM, during which the pressure dropped by only $0.4 \mathrm{hPa}$ (the pressure drop intensity was $0.1 \mathrm{hPa} / \mathrm{h}$ at that time) and the second, during which the pressure dropped by $2.7 \mathrm{hPa}$ during $5 \mathrm{~h}$. During this period, the average rate of pressure drop was $0.54 \mathrm{hPa} / \mathrm{h}$.

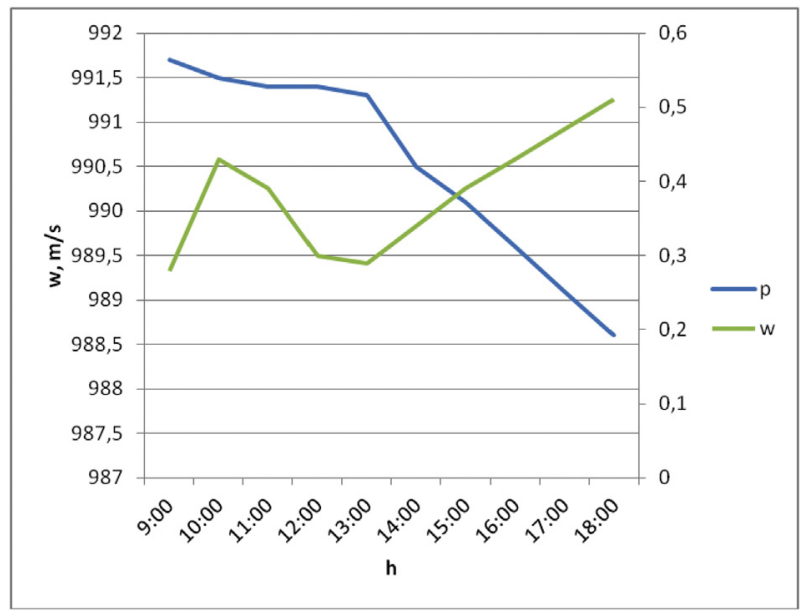

Fig. 6. Pressure variation and emissions velocity at the point $E$ on 23.05.2020.
Fig. 6 shows an increase in the gas emissions velocity from 1:00 PM to 6:00 PM from $0.29 \mathrm{~m} / \mathrm{s}$ to $0.51 \mathrm{~m} / \mathrm{s}$. In the time period from 8:00 AM to 1:00 $\mathrm{PM}$, the speed increased from $0.28 \mathrm{~m} / \mathrm{s}$ to $0.43 \mathrm{~m} / \mathrm{s}$.

Regardless of the variable emissions velocity, during 9:00 AM - 1:00 PM, the concentration of $\mathrm{CO}_{2}$ in the emitted gases increased from $0.06 \%$ vol. up to $0.29 \%$ vol. and later until $18: 00-0.48 \%$ vol. (Fig. 7).

Analysing Fig. 8, it can be seen that the oxygen concentration in the emitted mixture decreased from the value of $20.8 \%$ vol. down to $20.1 \%$ vol. during the time from 9:00 AM to 6:00 PM, but from 8:00 AM to 1:00 PM, when the pressure drop rate was $0.1 \mathrm{hPa} / \mathrm{h}$, oxygen concentration decreased by $0.4 \%$ vol. in the first hour of the pressure drop, then it remained at this level until 1:00 PM. Then, when pressure drop rate increased it started to fall once again.

\subsection{Example 2 - August 22nd 2020}

As the TEXMIN project aims to assess the impact of extreme weather events, including their influence on closed mines, on August 22nd 2020, measurements of gas emissions from shaft II were carried out in the period before the approaching intense storm (Figs. 9-11).

The measurements were carried out from 2:00 $\mathrm{PM}$ to 6:00 PM. The pressure dropped by 5:00 PM from the value of $982.5 \mathrm{hPa}$ to $981.0 \mathrm{hPa}$, but by analysing the meteograms of the history of pressure changes at that time, the reduction lasted from 11:00 AM when the pressure value was $983.5 \mathrm{hPa}$. Thus, the pressure drop lasted $6 \mathrm{~h}$ and

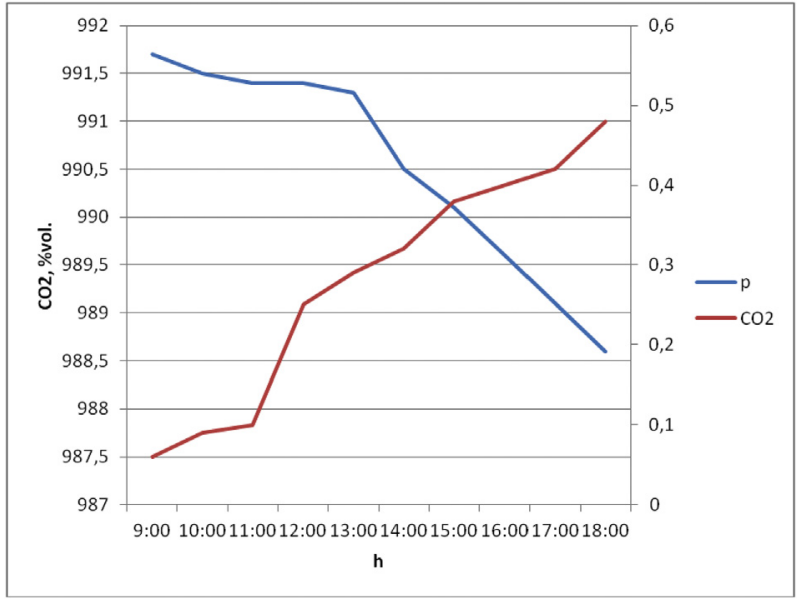

Fig. 7. Pressure variation and $\mathrm{CO}_{2}$ concentration at the point $\mathrm{E}$ on 23.05.2020. 


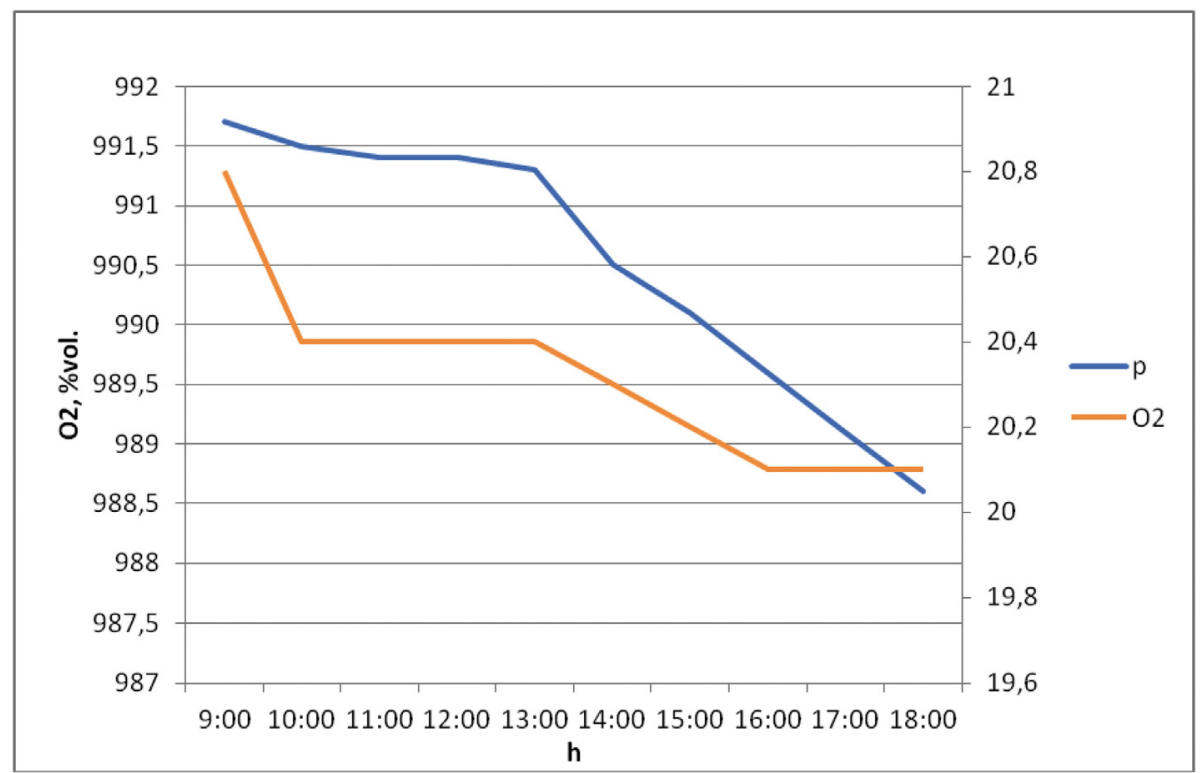

Fig. 8. Pressure variation and $\mathrm{O}_{2}$ concentration at the point $E$ on 23.05.2020.

the pressure dropped by $2.5 \mathrm{hPa}$. Therefore, the pressure drop rate was $0.41 \mathrm{hPa}$. At 5:00 PM the atmospheric front passed through the measuring point and the pressure began to rise. By 6:00 PM it had increased to $982.0 \mathrm{hPa}$. An intense storm began at this time, which made further measurements impossible.

When analysing Fig. 9-10, it can be seen that from 5:00 PM to 6:00 PM the emissions from shaft II stopped. The emissions velocity dropped from $0.41 \mathrm{~m} / \mathrm{s}$ to $0 \mathrm{~m} / \mathrm{s}$. At that time, the concentration of $\mathrm{CO}_{2}$ in emitted gases also decreased from $2.37 \%$ vol. to background value $(0.056 \%$ vol.) and the oxygen concentration increased from $18.4 \%$ vol. to $20.9 \%$ vol. (Figs. 10 and 11).

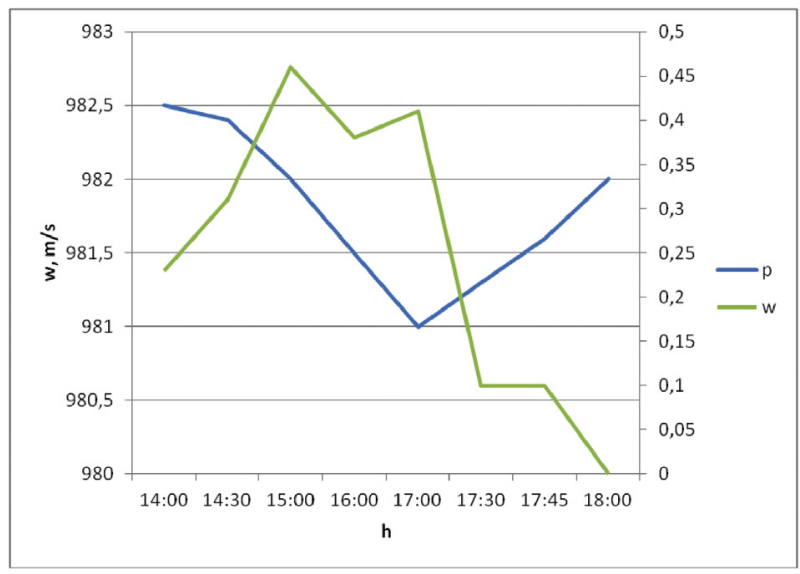

Fig. 9. Pressure variation and emissions velocity at the point $E$ on 22.08.2020.

\subsection{Example 3 - June 3rd 2020}

Figs. 12-15 show the examples of the results obtained from the measurements of the distribution of $\mathrm{CO}_{2}$ and $\mathrm{O}_{2}$ concentrations around the shaft II on June 3rd 2020 at 9:00 AM.

At that time, pressure was $975.5 \mathrm{hPa}$ and it was the final stage of the pressure drop starting on June 2nd 2020 at 11:00 AM at a pressure of $982.0 \mathrm{hPa}$. Thus, the pressure drop lasted $20 \mathrm{~h}$ and the pressure drop was $6.5 \mathrm{hPa}$. Therefore, the pressure drop rate was $0.33 \mathrm{hPa} / \mathrm{h}$. The pressure value stabilized from 7:00 AM on June 3rd 2020. The concentration of $\mathrm{CO}_{2}$ in the emitted gases was $7.51 \%$ vol. and the oxygen concentration was $6.8 \%$ vol. The emissions velocity was $0.1 \mathrm{~m} / \mathrm{s}$ (as a result of slowing down the

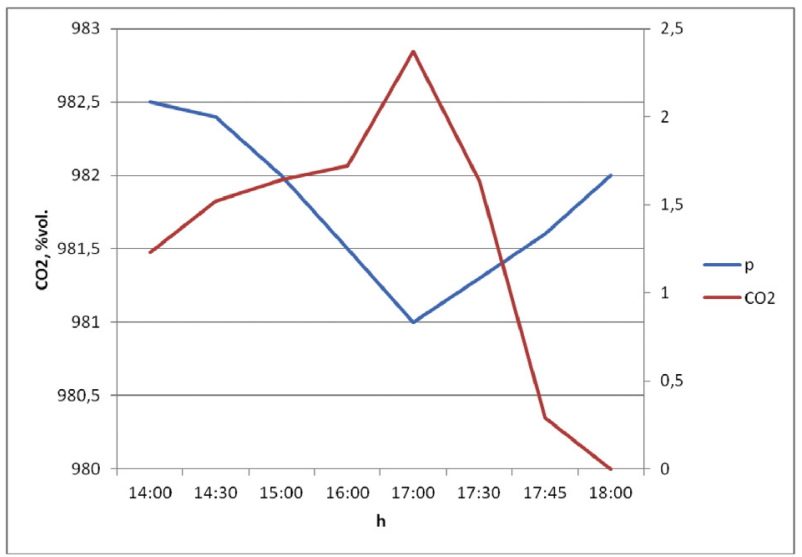

Fig. 10. Pressure variation and $\mathrm{CO}_{2}$ concentration at the point $E$ on 22.08.2020. 


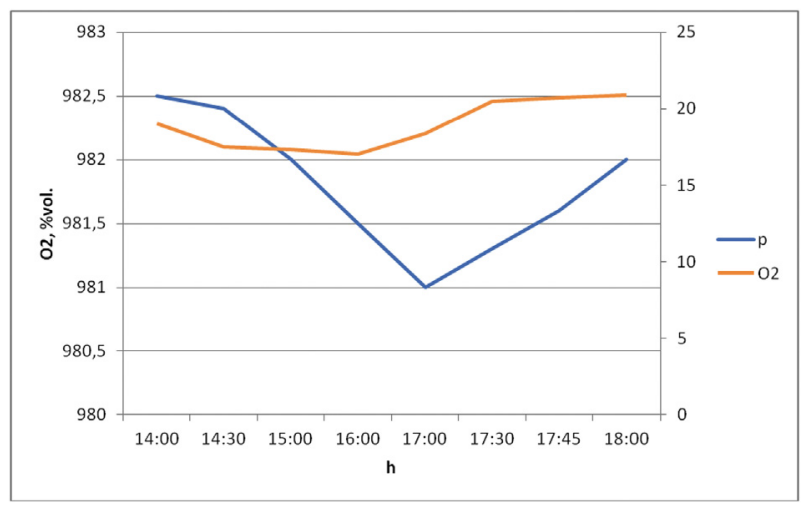

Fig. 11. Pressure variation and $\mathrm{O}_{2}$ concentration at the point $E$ on 22.08.2020.

pressure drop). The ambient temperature was $17.1{ }^{\circ} \mathrm{C}$ and the temperature of the emitted gases was $15.9{ }^{\circ} \mathrm{C}$. The wind speed $0.4-0.8 \mathrm{~m} / \mathrm{s}$ was from the south.

Analysing the results (Figs. 12 and 13) it can be seen that at the ground level $\mathrm{CO}_{2}$ concentration is $7.51 \%$ vol. at the $\mathrm{E}$ point. Within a radius of $20 \mathrm{~m}$ from the shaft the value is higher than $0.4 \%$. Considering values at the height of $1 \mathrm{~m}$, there is $\mathrm{CO}_{2}$ concentration $4.5 \%$ vol. above point E. Within a radius of $25 \mathrm{~m}$ from the shaft the value is higher than $0.2 \%$ vol.

Analysing the results (Figs. 14 and 15) it can be seen that at the ground level $\mathrm{O}_{2}$ concentration is $6,8 \%$ vol. at the E point. Within a radius of $20 \mathrm{~m}$ from the shaft the value is lower than $20.4 \%$ vol. Considering values at the height of $1 \mathrm{~m}$, there is $\mathrm{O}_{2}$ concentration $18.8 \%$ vol. above point E. Within a radius of $30 \mathrm{~m}$ from the shaft the value is lower than $20.7 \%$ vol.

\section{Insights and conclusions}

Basing on presented examples following insights and conclusions can be drawn:

1. On May 23rd 2020, two stages of pressure drop were observed, the first less intense $(0.1 \mathrm{hPa} / \mathrm{h})$ and the second more intense $(0.54 \mathrm{hPa} / \mathrm{h})$. The change in the intensity of emission influenced on the gas emissions rate (increase in the second stage) and the change in oxygen concentration (more intense decrease in the second stage). The concentration of $\mathrm{CO}_{2}$ in the emitted gases increased with the same intensity during both stages of the pressure drop.

2. On August 22nd 2020 pressure was falling before the upcoming storm (an extreme weather event). At 5:00 PM, an hour before the storm, baric tendency had changed to pressure rise. At 6:00 PM emissions stopped. Carbon dioxide concentration and oxygen concentration returned to background values. During that time (5:00 PM-6:00 PM) the emissions velocity dropped from $0.41 \mathrm{~m} / \mathrm{s}$ to $0 \mathrm{~m} / \mathrm{s}$. Concentration of $\mathrm{CO}_{2}$ in emitted gases also decreased from $2.37 \%$ vol. to background value $(0.056 \%$ vol.) and the oxygen concentration increased from $18.4 \%$ vol. to $20.9 \%$ vol. This observation leads to a conclusion that the pressure drop process should be investigated in detail considering hourly or even more frequent variations of pressure.

3. On June 3rd 2020, isoline maps of $\mathrm{CO}_{2}$ and $\mathrm{O}_{2}$ concentration were determined in vicinity of the shaft II. The article presents exemplary results for 9:00 AM, when the $\mathrm{CO}_{2}$ concentration was $7.51 \%$, and the $\mathrm{O}_{2}$ concentration was $6.8 \%$ vol. in

Location of measurements points: at ground level

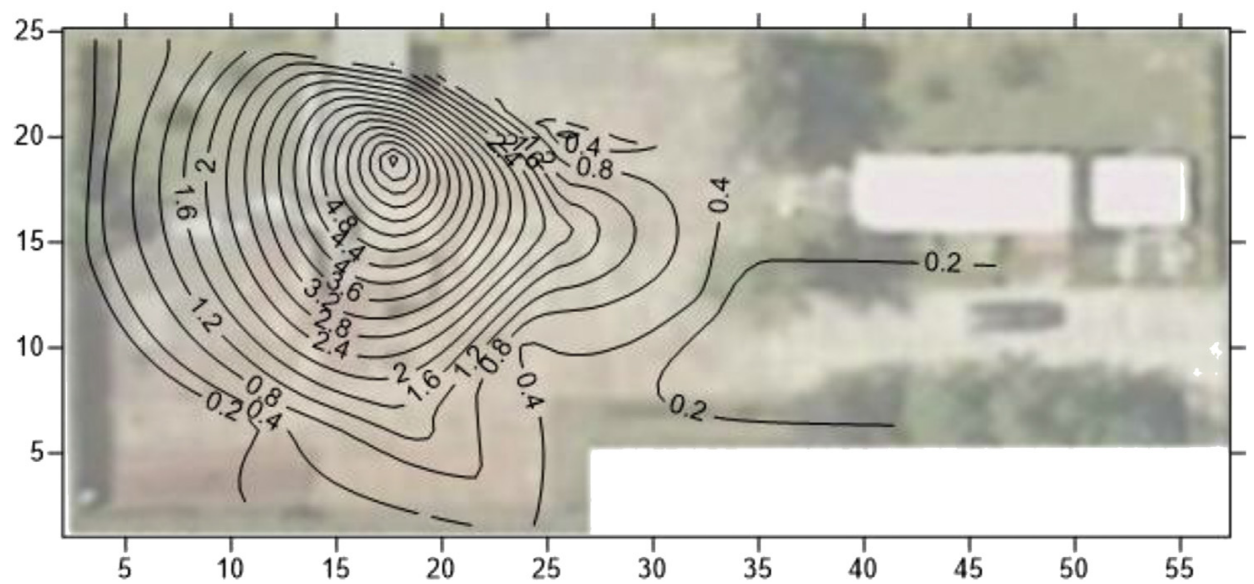

Fig. 12. Concentration of $\mathrm{CO}_{2}$ at ground level in vicinity of II shaft on June, 3rd 2020, 9:00 AM. 
Date: 3th June2020

CO2 concentration, \%vol.

Time: 9:00

Location of measurements points: $1 \mathrm{~m}$ above the ground level

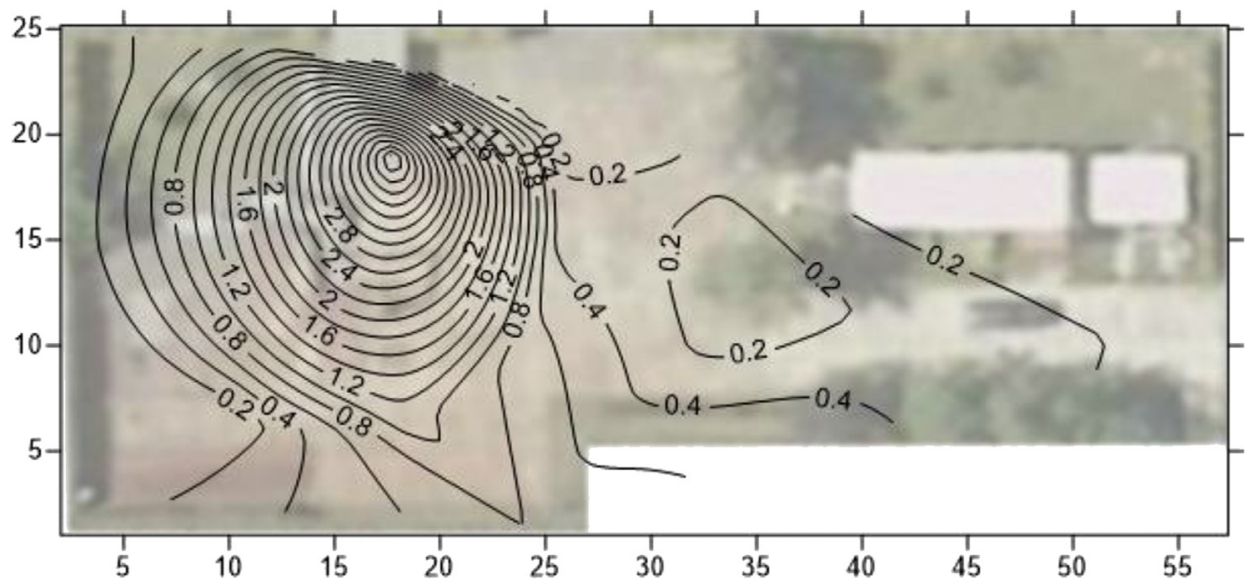

Fig. 13. Concentration of $\mathrm{CO}_{2}$ at $1 \mathrm{~m}$ in vicinity of II shaft on June, 3rd 2020, 9:00 AM.

Date: 3th June2020

Time: $9: 00$

O2 concentration, \%vol.

Location of measurements points: at ground level

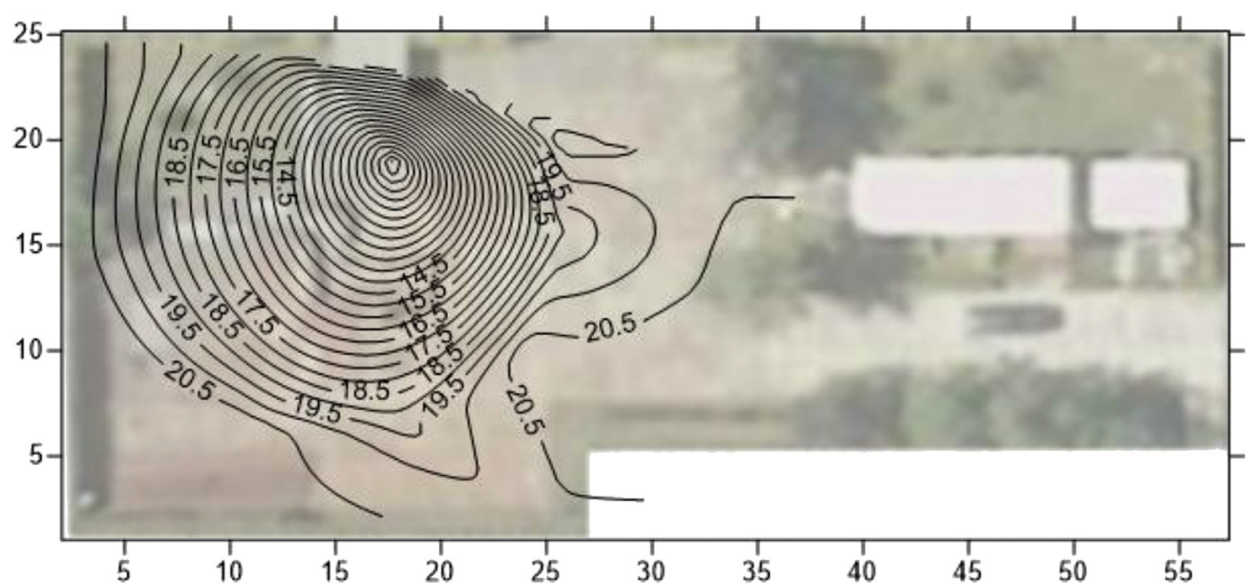

Fig. 14. Concentration of $\mathrm{O}_{2}$ at ground level in vicinity of II shaft on June, 3rd 2020, 9:00 AM.

Date: 3th June2020

Time: 9:00

Location of measurements points: $1 \mathrm{~m}$ above ground level

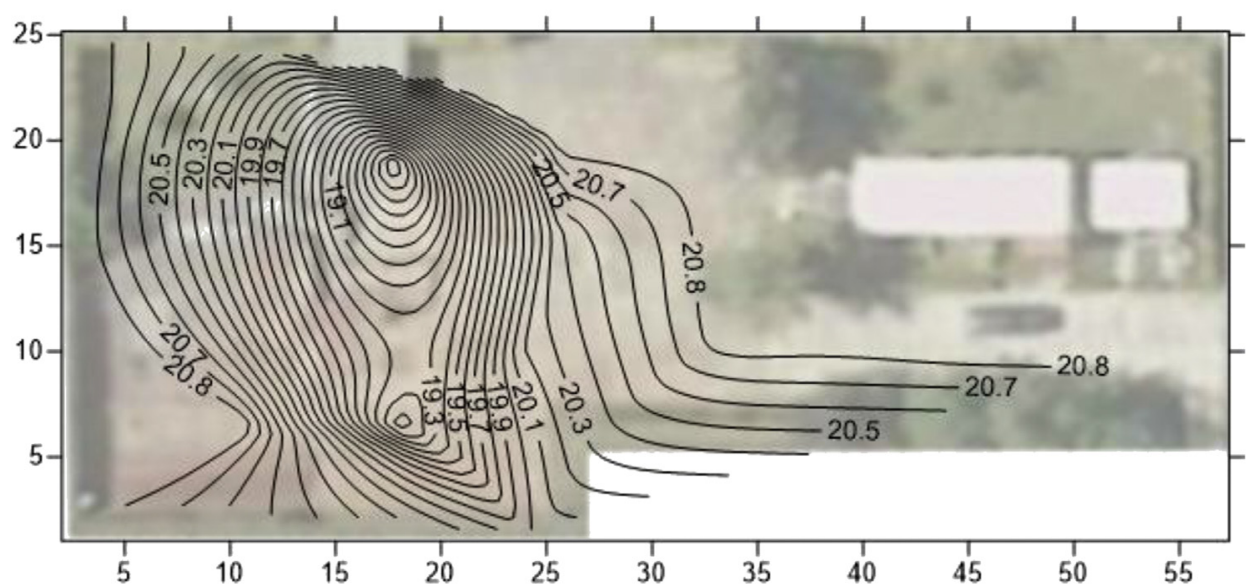

Fig. 15. Concentration of $\mathrm{O}_{2}$ at $1 \mathrm{~m}$ in vicinity of II shaft on June, 3rd 2020, 9:00 AM. 
the gases emitted from the shaft (point E). The $\mathrm{CO}_{2}$ concentration at ground level within a radius of $20 \mathrm{~m}$ from the shaft was higher than $0.4 \%$, and at $1 \mathrm{~m}$ within a radius of $25 \mathrm{~m}$ from the shaft the value was higher than $0.2 \%$ vol. Considering oxygen concentration, at the ground level within a radius of $20 \mathrm{~m}$ from the shaft the value was lower than $20.4 \%$ vol. and at $1 \mathrm{~m}$ within a radius of $30 \mathrm{~m}$ from the shaft the value was lower than $20.7 \%$ vol.

The results will be the base for further numerical modelling, when the results will be used for validation of the models as well as for development of risk mitigation strategies (i.e. determination of a safe distance from a closed shaft).

\section{Ethical statement}

The authors state that the research was conducted according to ethical standards.

\section{Funding body}

This project has received funding from the Research Fund for Coal and Steel under grant agreement No. 847250 TEXMIN "The Impact of Extreme Weather Events on Mining Operations".

The research is published in the frameworks of international project, co-funded from financial means of Ministry of Science and Higher Education "PMW" in the years 2019-2022, agreement no. 5009/ FBWiS/2019/2.

\section{Conflicts of interest}

None declared.

\section{References}

[1] Wrona P, Różański Z, Pach G, Suponik T, Popczyk M. Closed coal mine shaft as a source of carbon dioxide emissions. Environ. Earth Sci 2016;75:1139. https://doi.org/10.1007/ s12665-016-5977-7.

[2] Wrona P. The influence of climate change on $\mathrm{CO} 2$ and $\mathrm{CH} 4$ concentration near closed shaft - numerical simulations. Arch Min Sci 2017;62(3):639-52. https://doi.org/10.1515/ amsc-2017-0046.

[3] Duda A, Krzemień A. Forecast of methane emission from closed underground coal mines exploited by longwall mining - a case study of Anna coal mine. J Sustainable Mining 2018;17(4):184-94. https://doi.org/10.1016/j.jsm.2018.06.004.

[4] Szlązak N, Obracaj D, Borowski M. Zagrożenie gazami kopalnianymi $\mathrm{w}$ obiektach budowlanych na terenach zlikwidowanych kopalń podziemnych. Przeglad Gorn 2002; 58(7-8):42-58.

[5] Krause E. Kształtowanie sie zagrożenia metanowego w likwidowanej kopalni. In: Proceedings of the XX conf. Metan i inne zagrożenia współwystępujące - teoria i praktyka" Publisher NOT-SITG; ROP Rybnik; 2003. 1 Maja.
[6] Krause E, Pokryszka Z. Investigations on methane emission from flooded workings of closed coal mines. J Sustain Mining 2013;12(2):40-5. https://doi.org/10.7424/jsm130206.

[7] Wrona P, Sułkowski J, Różański Z, Pach G. The problem of carbon dioxide emissions from closed coal mine shafts - the overview and the case study. Arch Min Sci 2016;61(3): 587-600. https://doi.org/10.1515/amsc-2016-0042.

[8] Broughton P. Developing approaches to the control of risk from abandoned mine entries. In: Proceedings of the 9th safety seminar, safety managing the challenge change. Sheffield: The Midland Institute of Mining Engineers; 2014 p. 47-61.

[9] Franklin P, Scheehle E, Collings RC, Cote MM, Pilcher RC Proposed methodology for estimating emission inventories from abandoned coal mines. 2006 IPCC guidelines for national greenhouse gas inventories fourth authors/experts Meeting: energy (28-30 september 2004), vol. 2; October 2004. p. 64. Retrieved November 9, 2017.

[10] Krzemień A, Sánchez AS, Fernández PR, Zimmermann K, González CF. Towards sustainability in underground coal mine closure contexts: a methodology proposal for environmental risk management. J Clean Prod 2016;139:1044-56. https://doi.org/10.1016/j.jclepro.2016.08.149.

[11] Wrona P. Ocena zagrożenia gazowego na terenach pogórniczych kopalń węgla kamiennego - rola zlikwidowanego szybu górniczego, Monografia habilitacyjna. Gliwice: Wydawnictwo Politechniki Sląskiej; 2018.

[12] Bystroń H. Analityczna metoda badania stabilności pracy wentylatorów głównych $\mathrm{w}$ kopalnianych sieciach wentylacyjnych traktowanych jako układy o stałych skupionych", Prace GIG, Komunikat nr 576. Katowice 1973:54-5.

[13] Sułkowski J, Wrona P. Mathematical model of gas out flow from abandoned coal mine through untight shaft under the influence of atmospheric pressure changes. Arch Min Sci 2006;51(1):97-107.

[14] Kulczycki Z, Grzybek I. Gazy kopalniane jako zagrożenie dla bezpieczeństwa powszechnego. Miesięcznik Bezpieczeństwo Pracy i Ochrona Srodowiska w Górnictwie 1999;1:16-25.

[15] Grzybek I, Kędzior S. Zróżnicowanie warunków gazowych Górnośląskiego Zagłębia Węglowego, a możliwość migracji metanu ze zlikwidowanych kopalń węgla kamiennego. Zeszyty Naukowe Pol Śl Seria Górnictwo z 2005;268:55-66.

[16] Kotarba M. Gas hazard in the near-surface zone of the Wałbrzych coal mine closure: geological and geochemical controls. Wydawnictwo Akapit; 2002.

[17] Mamadou F, Othman N, Nguyen TS. A coupled hydro-mechanical model for simulation of gas migration in host sedimentary rocks for nuclear waste repositories. Eng Geol 2014;176:24-44. https://doi.org/10.1016/j.enggeo.2014.04.003.

[18] Krzystolik P, Kobiela Z. Powierzchniowa emisja metanu na obszarach zlikwidowanych kopalń - zagrożenia dla środowiska naturalnego i bezpieczeństwa ogólnego. Zesz Nauk Pol Śl Seria Górnictwo z 2000;246:52-67.

[19] Dziurzyński W, Krach A, Krawczyk J, Pałka T. Migracja gazów z szybu zlikwidowanej kopalni. Szkoły Aerologii Górniczej 2004:67-180. Mat. 3; Zakopane 12-15.10.04.

[20] Cheng L, Ge Z, Xia B, Li Q, Tang J, Cheng Y, et al. Research on hydraulic technology for seam permeability enhancement in underground coal mines in China. Energies 2018;11:427. https://doi.org/10.3390/en11020427.

[21] Chećko J. Geologiczne aspekty migracji gazów kopalnianych na powierzchnię w przypadku likwidacji kopalń węgla kamiennego. WNP; 2008. https://www.wnp.pl/wiadomosci/ geologiczne-aspekty-migracji-gazow-kopalnianych-napowierzchnie-w-przypadku-likwidacji-kopaln-weglakamiennego,-4742.html.

[22] Pokryszka Z, Tauziède C, Lagny C, Guise Y, Gobillot R, Planchenault JM, et al. Gas migration from closed coal mines to the surface risk assessment methodology and prevention means. Symposium Post-mining 2005. November 16-17, Nancy, France. https://inis.iaea.org/search/search.aspx?orig $\mathrm{q}=\mathrm{RN}: 38027836$. 